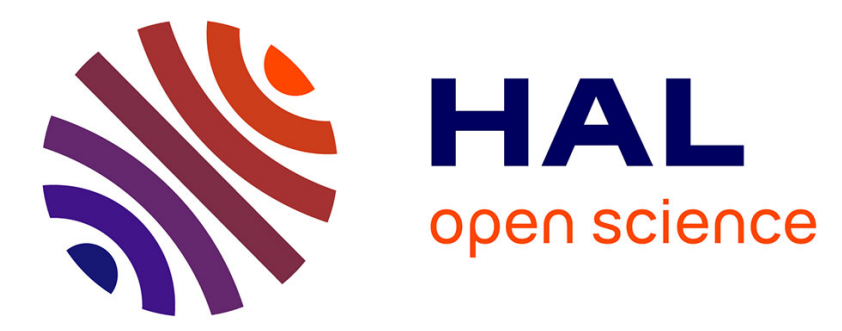

\title{
Integrating a Popular Sport into the Patrimony in a South African Provincial Town: The Case of Football in Stellenbosch
}

Sylvain Cubizolles

\section{- To cite this version:}

Sylvain Cubizolles. Integrating a Popular Sport into the Patrimony in a South African Provincial Town: The Case of Football in Stellenbosch. African Studies, 2012, 71 (1), pp.108-126. 10.1080/00020184.2012.668296 . hal-01232315

\section{HAL Id: hal-01232315 \\ https://hal.univ-reunion.fr/hal-01232315}

Submitted on 27 Oct 2016

HAL is a multi-disciplinary open access archive for the deposit and dissemination of scientific research documents, whether they are published or not. The documents may come from teaching and research institutions in France or abroad, or from public or private research centers.
L'archive ouverte pluridisciplinaire HAL, est destinée au dépôt et à la diffusion de documents scientifiques de niveau recherche, publiés ou non, émanant des établissements d'enseignement et de recherche français ou étrangers, des laboratoires publics ou privés. 


\title{
Integrating a Popular Sport into the Patrimony in a South African Provincial Town: The Case of Football in Stellenbosch
}

\author{
Sylvain Cubizolles*
}

\author{
Université de La Réunion
}

The awarding of the 2010 World Cup to South Africa was presented as an enormous achievement for South Africans. It was believed that one of the many benefits would be that tourism would be given a community-oriented focus. In the light of this, the Stellenbosch Municipality, situated in the Western Cape, launched the 'Great Stellenbosch 2010' project in 2006. As part of the project, the black township of Kayamandi was given a building to promote tourism in the Stellenbosch area and to enhance infrastructure in the township. However the coloured football community of Stellenbosch contested the project. This article describes the local club structure and local political circumstances. A series of interviews reveal the disaffection felt by the coloured community about the building in the black township. The article also describes how the initiative actually inflamed old race-based divisions between the black and coloured communities and sowed confusion around the symbol of togetherness that the World Cup was meant to embody.

This article is a study of the reception of a football-based municipal tourist initiative created during the run-up to the 2010 World Cup in South Africa, in Stellenbosch, a town in the Western Cape. In it I analyse the responses of the two major football playing groups - the coloureds and the Africans - and those of the Stellenbosch Local Football Association (SLFA), which organised the activity. The project involved a tourism building located on the outskirts of Kayamandi, the township of the town. The building, named the Kayamandi Economic and Tourism Corridor (KETC), had been there since 2006, but had not been in use. In the project, the KETC was made the official building of the 2010 World Cup in Stellenbosch, with a view to energising it and attracting the economic benefits of tourism through football to the African part of the town. The project also publicly endorsed the idea that in Stellenbosch football was essentially a feature of the culture of the township. Among the African footballers in Kayamandi, except for a few reservations, the initiative was greeted as a good measure aimed at economic adjustment, considering the apartheid past, and as recognition of the African group's passion for the sport at national level. On the other hand, it was considered a form of symbolic violence by the coloured footballers, who resented the project which ignored their

*Email: sylvain.cubizolles@univ-reunion.fr 
longstanding football history in the town and inadequately represented the widely shared passion for football in Stellenbosch. The SLFA believed that the initiative not only reproduced, but fuelled divisions from the past, and felt that they should have been asked for their advice at the time when the project was being developed.

There were several stages to my research, which began during an initial two-week visit in April 2008. I came back for another two weeks in April 2009, and again in June 2010 (during the World Cup), in September 2010 and September 2011. In the course of those visits I was able to build several data clusters. The first one includes semi-directive interviews, which I conducted with the main actors on the football stage of the town, as well as with all the persons involved in the 'Greater Stellenbosch 2010' project. In 2008 and 2009 I interviewed an officer in charge of the Sport and Recreation Department in Stellenbosch, and three members of the SLFA steering committee. Also included are interviews of people in charge of African clubs, which I conducted in 2008 and 2009 - two from the Mighty 5 Star, one from the Mighty Peace and one from United Colours, as well as interviews with five footballers who play for them. There are also interviews with officers from coloured clubs, in 2008 and 2009 - one from the Newtons club, one from Spes Bona, one from Jamestowns, one from Idas Valley Homestay and one from the Sparkling Star, as well as interviews with four footballers who play for them. Finally, there are interviews with two officers from Maties, the Stellenbosch University club.

The second cluster of data includes articles on the KETC in public life in Stellenbosch. I collected them from the town council newspaper, the Stellenbosch Newsletter, the local newspaper Eikestad News, the regional newspaper Cape Times, the Stellenbosch Tourist Board website, and the Internet. The third data group comes from participatory observation made during my different visits (in 2008, 2009, 2010 and 2011), when I visited the KETC several times and saw for myself what changes had occurred and how the building was being used.

Firstly, I describe the football order in Stellenbosch and how the 'Great Stellenbosch 2010 ' project was created, so as to situate the KETC and its tourist identity in relation to football and the township. Secondly, I discuss how the building was received among the African and coloured footballers, and how the SLFA felt about the initiative. Thirdly, I turn to the public representation of football in Stellenbosch and, based on the results of the investigation, I extend the discussion to the issue of how popular culture is absorbed into the patrimony and making of heritage in the post-apartheid era. This includes two contrasting desires - how to please international tourists on the one hand, and on the other how to develop a cultural heritage breaking away from the history of apartheid.

\section{The Football World in Stellenbosch}

Stellenbosch is a town located 70 kilometres east of Cape Town, at the heart of the wine-producing region of Boland. The population is 140,000 and includes 55 per cent coloureds, 24 per cent Africans and 21 per cent whites (Zietsman 2007). In 
the town, football is not as prestigious as rugby or cricket. Historically, it is not associated with the elite, nor is it supported by the academic institutions of excellence of the town, such as the University of Stellenbosch or the private schools in the white parts of the town. The university football club was only founded in 1947, whereas the cricket and the rugby clubs were created as far back as 1866 and 1875 respectively. And yet, football has long been played in Stellenbosch, where it developed among the coloureds, as shown by the creation of Spes Bona, one of the coloured clubs involved in this survey, as early as 1929. However that was not enough to make football a symbol of the town, at least not for the mainstream.

Nowadays the three major South African population groups - whites, coloureds and Africans - practise football in a unified league. Football has been played since 2006 under the aegis of the SLFA, which is accredited by the South African Football Association (SAFA). In 2009 it included 42 clubs, although not all the clubs in the town belong to it. It represented 6,000 licensed players, which according to the SLFA chairperson, makes football by far the most popular sport in Stellenbosch, well ahead of rugby or any other sport in the muni-cipality. The only sports institution that can boast a larger number of licensed players than SLFA is the University of Stellenbosch, with its many sports branches.

Of the 42 clubs that make up SLFA, two-thirds come from the coloured parts of the town, one-third from the African township, and one club from the white area. That the majority are coloured clubs gives them the feeling that they are the natural representatives of football in the town. The reason why African clubs are so few in SLFA is first that their football history only began in Stellenbosch in about 1972, as is the case for the Mighty 5 Star, the oldest of the African clubs included in the survey. Another reason is that they find it difficult to work in conformity with SLFA rules, because not all African clubs consider themselves as sports firms, in the sense used by federations. Lastly, only one club labelled as belonging to the white population of Stellenbosch is representative of the latter's interest in football. However, they are committed through a powerful institution, the university and its Maties club. ${ }^{1}$

In 2006 the three leagues ${ }^{2}$ that had existed since 1994 were joined, but, perversely, the differences between the various football groups became more marked. The degree of competition between them intensified, as they were aiming at the same sports objectives but the inequality between them was highlighted. The competition was so intense that the football groups, instead of drawing together, moved further apart sometimes linking identity to geographic location rather than joint solidarity (Cubizolles 2011).

Indeed the rivalry between coloured and African footballers heightened as the town prepared to host the 2010 World Cup. Each group mobilised its own resources to jostle for a position on the football stage of the town, so as to have the right to participate in the event, and benefit from it in due course. It was an 
opportunity to request assistance from the municipality for equipment, or to ask the local businesses, which traditionally support rugby and cricket, to give them some long-awaited financial support. In a more general way, in Stellenbosch the 2010 World Cup was perceived as an opportunity to change the image of football or, as the SLFA chairperson put it, 'to make the sports mentality of the town change'. ${ }^{3}$ However, this was not to be.

\section{Tourism in Stellenbosch and the 'Great Stellenbosch 2010' Project}

Since the end of apartheid, South Africa has received more and more foreign visitors and has strengthened its position as a tourist destination. The number of visitors rose from 4 million in 1994 to 6.7 million in 2003 and 9.7 million in 2008. ${ }^{4}$ The town of Stellenbosch, at the heart of the Cape Winelands, is particularly attractive to foreign tourists, who represent 90 per cent of visitors. European visitors - from Great Britain, Germany or Switzerland - come on holiday to Stellenbosch for its food and wine and its traces of old Dutch and French culture. ${ }^{5}$

Tourism is thus a prosperous economic sector. In 2007 Stellenbosch Tourism Information (STI) recorded 1,118,740 nights spent there, and estimated that the money generated by STI members in the local economy was R1,320,714,578. ${ }^{6}$ Though it is difficult to say what tourism represents in terms of jobs, the amount annually dedicated for its development is a reminder of its important role in the local economy dynamics. For the 2010 World Cup, the town council provided the Local Tourism Association with a R2,050,000 subsidy. ${ }^{7}$ For Stellenbosch, a town dedicated to cultural tourism intended for foreign visitors, 2010 appeared to be an event not to be missed.

The 'Great Stellenbosch 2010' project apparently stemmed from the idea that the town could accommodate a national team during the world tournament, so that a flow of supporters would be drawn to the town, which would benefit its tourist economy. But very little real thought went into how community-based tourism would fit into what was already there.

In March 2008, in an article titled '2010 Soccer World Cup, how will the greater Stellenbosch benefit?', David Daniels, a municipal manager and a member of the Democratic Alliance (DA) team headed by Lauretta Maree, then mayor of Stellenbosch, explained the intention underlying the birth of the municipal project as follows:

The 2010 World Cup should leverage social development for the Stellenbosch communities and leave behind it both a 'hard legacy' that would generate infrastructure, training, jobs, tourist activities, and a 'soft legacy' that would help initiate greater social cohesion and wipe out the racial and economic exclusion resulting from apartheid. $^{8}$ 
In January 2009, the 'Stellenbosch 2010' municipal project and its strategy were presented in the Eikestad News, the town newspaper, with the headline 'Town's 2010 Strategy'. ${ }^{9}$ The strategy outlined three major aims - making Stellenbosch a host town for a team in the tournament, setting up giant screens in the different areas, and leaving a legacy that would remain after the tournament. On the latter point, the KETC was mentioned as a core tourism asset. It was expected to turn the Kayamandi township into 'the main centre of football focus for the community during 2010', and possibly host, among other attractions, a museum that would describe the football history of the town on the one hand, and honour the heroic career of certain local footballers on the other.

Besides the DEAT framework, the will to focus mainly on Kayamandi and publicly relate it to football by means of the KETC was strengthened by the change in the municipal team, after the African National Congress (ANC) and its leader, Patrick Swartz, took over from Lauretta Maree in April 2008. ${ }^{10}$ On the home page of the 'Great Stellenbosch 2010' website, ${ }^{11}$ the newly-elected ANC mayor posted how he intended to use 2010 to promote football and help the town-ship. He wished to restore the sport to its rightful place in Stellenbosch, and reminded readers how it had been played in the Boland townships since the $19^{\text {th }}$ century. He also expressed his wish that the economic and social benefits of the project would be to the advantage of the least privileged groups and would offer opportunities for sustainable development. Mr Gerald, the officer in charge of the Sport and Recreation department in Stellenbosch, explicitly expressed his intention to focus the 'Great Stellenbosch 2010' project on Kayamandi because of football:

\footnotetext{
There is a will to make Kayamandi a major site for the project; football is the sport of the townships, with the 2010 World Cup it can help the area develop. The KETC is a good tool for this, it will help promote Kayamandi. It will be a showcase that helps tourists discover its culture. ${ }^{12}$
}

The 'Great Stellenbosch 2010' municipal project, as defined in 2009, was thus making KETC one of its key elements. In the view of the 2010 World Cup, it was intended to act as a tourist centre geared towards football, where visitors could both celebrate the World Cup and discover the African passion for the sport in the township.

\section{The KETC in the 'Great Stellenbosch 2010' Project}

In the turmoil of the preparation for the 2010 World Cup, the football-related future of the KETC was clearly spelt out. A structure intended for tourism, it was meant to contribute to the area's economic development and to help the residents live in sustainable dignity. ${ }^{13}$ The town authorities identified it as a priority component of the Kayamandi Urban Renewal (KUR) project. The construction work began in 2005, was completed in 2006, and in a 2007 municipal report, the town authorities deemed the project 95 per cent complete. ${ }^{14}$ 
By then, the only issue still left for the KETC was how to allocate the contracts among the private partners. The question of its social role and its contents had been decided upon previously. It was conceived as 'a catalyst for social change and racial tolerance as well as a centre that will promote cultural expression and economic development within Kayamandi' ${ }^{15}$ In its 2008 catalogue, builder Dennis Moss Partnership ${ }^{16}$ described the tourism contents of the KETC more specifically: 'The centre will comprise an anti-apartheid museum, amphitheatre, restaurant, Internet café as well as formal and informal kiosks'. However, in March 2008, as an article titled 'Status of the Kayamandi Tourism Precinct ${ }^{17}$ showed, the project was delayed, due mainly to the lack of private partners who would propose viable projects to the town authorities.

That notwithstanding, the new mayor, Patrick Swartz, opened the KETC on 31 October 2008, though the yard still remained empty. In 2009 the newly elected ANC municipal team picked up the 'Great Stellenbosch 2010' project again, highlighting the KETC as a major component - to receive tourists in Stellenbosch, celebrate football, and strengthen the tourist economy in Kayamandi. At the time, Mr Gerald, the officer in charge of the Sport and Recreation Department in Stellenbosch, explained to me:

The KETC will be a centre of attraction which by means of football is intended to
make Kayamandi more accessible to tourists. Now Kayamandi has a lot to offer to
tourists. It is a lively, living place. Tourists will be able to learn more on South
Africa. If you come to Stellenbosch on a visit, you must meet with all the cultures
that thrive there. If you only visit the streets downtown, you would miss a lot, Stellen-
bosch is made up of different cultures. ${ }^{18}$

The town authorities strove to publicly identify the KETC as the sanctuary of football culture in Stellenbosch. A project was announced concerning the creation of a museum; ${ }^{19}$ a ceremony featuring a legend of South African football, Doctor Khumalo, was organised on 15 September 2009, when mayor Patrick Swartz said that 'Doctor Khumalo's presence will inspire the kids to change Stellenbosch into a soccer town and to become a soccer nation in Stellenbosch and surrounding areas' ${ }^{20}$ As a prelude to the events themselves early in 2010 a leaflet was published $^{21}$ presenting the tourism activities related to the World Cup and to Kayamandi. The leaflet emphasised two points. Firstly, that the KETC 'has endorsement from the 2010 role-players as an official site and as such will be the hub of tourist activity in and out of Stellenbosch'. The activities included TV broadcasts of the matches on a giant screen, a craft market, an African restaurant, hosting an international team during the tournament, and making a variety of services and products available while the competition was in full swing. Secondly, the KETC was described as 'an initiative of Stellenbosch Municipality toward job and wealth creation and revitalisation of the local Kayamandi community'. Thanks to the 2010 World Cup, the building and its odd architecture, located on the outskirts of Kayamandi, was expected to get started and attract tourists, owners, investors and sponsors into its premises. The architecture, which 
builder Dennis Moss Partnership described as 'using structures with Cape Vernacular forms to create traditionally formed space', ${ }^{22}$ formed an elongated, eclectic, spacious building which did 'not carry the exclusive identity of any particular era or architectural movement; nor can it belong to any current cultural group, or represent the exclusive character of any particular domain' ${ }^{23}$ it included three floors: the highest one, a round-shaped place with a large mosaic in the middle, is the entrance hall; on the middle floor, also round, is a lecture hall for 250 people; and lower down is a triangle-shaped place for informal shops. Its general appear-ance, with its high ochre walls, red roofs, airy roof gardens and large picture windows, was an explicit symbol of 'a sharp bend in the road, leaving behind an unfortunate period in the history of the town and heralding a new era of faith in the future'. ${ }^{24}$ The KETC, with its smart appearance, just as you enter Kayamandi, could thus temper the inhospitable impression that the first streets of the township might give, cluttered as they are with shacks in tight rows, food stalls, sputtering cars, and busy or lounging pedestrians. It thus introduced a con-trast with the former layout of the apartheid town and, as Shepherd (2008) has written concerning other sites, it stood as a critical mirror of the past. Its look, in which local traditional shapes are incorporated, also intimated that a brand of tourism based on solidarity, as is usually practised in the townships (Ramchander 2007), would be developed there.

In 2009 the prestige of the KETC, added to its mission of representing football for the town during the 2010 World Cup, brought increased attention to Kayamandi. The mission, which sounded promising, caused strong responses among the football community of Stellenbosch. I expand below on the arguments of the stakeholders as they discussed whether it was right to give the township's tourism building a football identity. Only then can we grasp both what was at stake, from a social viewpoint, for the local football groups, and what were the limits of incorporating a popular sports culture into the broader heritage of culture in South Africa.

\section{The Anger of the Coloured Footballers}

In Stellenbosch, as previously stated, the majority of footballers are coloured, and as a group they are the ones who have played football the longest in the town. As such, they felt that making the KETC, and indirectly the black area, the football symbol of the town in the 2010 World Cup, was a deep injustice. Because they felt they had been wronged, they never gave their support to the identity assigned to the building, and criticised it on four major grounds: that it was a political privilege related to a 'race' criterion; ${ }^{25}$ was not sustainable; met tourism-related expectations rather than any historical requirement; was a historical and cultural case of perjury and gave an incorrect version of football in the town. The KETC football project revived among the group a deep, recurrent feeling shared by the majority of the coloured population of the country - that they are given unfair treatment whenever the issue of symbolic representation and recognition of their identity is raised (Adhikari 2005). 
In the view of coloured footballers, that the KETC should publicly represent football in Stellenbosch primarily signalled a policy of preference for Africans, which had been in place more widely since 1994. As an officer of the Sparkling Star club bluntly stated:

The thing is, the township's policy just now is to assist the African community; they don't care about Idas Valley or Cloetesville. If you are black, you benefit from it. We have an ANC government these days, so the municipality just has to conform. So this building is in line with the policy in which Africans are assisted, not coloureds. As their party is almost the majority in the town council, Kayamandi benefits from that policy. It's been that way since $1994 .^{26}$

That policy was considered a double injustice vis-à-vis coloured footballers. The latter felt that they had been robbed - first of their status as a poor section of the population, which was in any case historically ignored; and secondly of their football identity, which was being publicly neglected. As an officer from the Idas Valley Homestay stated bitterly:

I think it's wrong. They can't give a building to one part of the town, or to one area, just based on complexion, and neglect other people ... The others too fought for freedom in this country; the others too are fighting against poverty. What image do they want to give? The other areas, the other communities too have the same needs; they too have a right to development. They built this building to show that we are all equal, to show that football is equally shared, and yet they gave it to one area only. ${ }^{27}$

The policy, which was illustrated in the 'Great Stellenbosch 2010' initiative, was sternly criticised. For example, a Newton club player made the following prediction for Stellenbosch:

The building will bring about jealousy and bitterness among the communities. It fosters racism, as we said previously; some will say that the Africans have been privileged compared with the coloureds. People here will be still more divided! Because those who get the privilege will think that they are stronger and better than we are, though it's not true. Nobody is better than anybody else. The project highlights only one community. To me, it's very unfair; everybody should have an opportunity to benefit from $2010 .^{28}$

The second criticism against the football identity of the KETC was that it was not sustainable, firstly because of the social characteristics of the area, which would cause the building to deteriorate very quickly. A Newton player predicted that:

It's unreasonable investing so much, because at Kayamandi the fields are over-used, and the lawn will never stand it. I think it will be the same with the tourist building. It will deteriorate; I think some of the glass windows are broken already. They'll never know how to keep it in a good condition, not over there anyway. ${ }^{29}$

Secondly, its identity failed to attract all the footballers in Stellenbosch - which in time would limit its outreach - because many of them identified the KETC as located in a dangerous area, Kayamandi, as a Spes Bona officer said: 
I think the location is not quite right. I think the town council made a mistake, building it at Kayamandi. They did that to advertise for the township and try to set up an economy of a sort there... You see, the people who play football in Stellenbosch, if they have to go there, will think: 'Why do I have to go into the township? Why do I have to go to a place where I don't feel safe - a place where I don't feel safe for my car, for my children?' I think the town council did not really think about it when they took the decision. ${ }^{30}$

The third criticism against the KETC's football identity was that it had been developed for tourism, in which the expectations and representations of foreign visitors has priority over accuracy about the real history of football in Stellenbosch. The criticism also indirectly highlighted the ambiguities concerning the image of the coloured population, an image which marks them as unfit to meet tourists' standard expectations, since they are identified neither as football players nor as suffering from poverty, as a Jamestowns player pointed out:

You are quite right, some parts of the Cloetesville area are just as poor as Kayamandi. But you see, the difference is that the international community and the foreign tourists all pay more attention to poverty in the townships than in the coloured areas. Townships are a symbol here; tourists want to see the shacks, the way the blacks live; it's a folklore image of South Africa. They don't want to see where the coloureds live. ${ }^{31}$

The fourth criticism against the KETC's football identity was that it was cultural perjury. It disowned the coloured football group, which in Stellenbosch had a right to represent, or to participate in representing that sport, because the group is so large and has been involved in the sport for so long. Coloured players felt that neglecting the sports history of the town, and in fact of the coloured footballers' group, was both a humiliation and disillusionment for them. In the post-apartheid era, just as during apartheid itself, official history and its public representations seemed to care little about grasping and transforming real local experiences. As a Spes Bona officer expressed it:

Yes, I do think the initiative is a form of exclusion. You see, clubs like Spes Bona, which is one of the oldest in Stellenbosch, will never get a single room for an office there. In my view, it's a way of writing history all over again, and not the best one at that. ${ }^{32}$

In fact, for coloured footballers in Stellenbosch, the football identity given to the KETC was seen as favouring Kayamandi and the culture of its residents; and also offering foreign tourists a version of football in conformity with their expectations, i.e. solely related to the African culture in the townships, even though such a version meant ignoring part of the local football history, in which coloured footballers had long played a major role. In that respect, the 2010 World Cup shattered the hopes they had once harboured about having their football culture celebrated in a spirit of social equity or of reparation equity after the segregated past.

\section{The Football Identity of the KETC}

In Stellenbosch, African footballers are in a paradoxical position - they are a minority, though they are recognised as the largest of the groups who have a passion 
for the sport in South Africa. In such a context, it was a significant sign of recognition that the KETC was given a football identity supported by the town authorities. This was proof that the promises of the 2010 World Cup, which was primarily intended for Africans, had been kept, and that for their group the great tournament had turned out to be the form of accomplishment that had been promised (Alegi 2009). The majority of the footballers interviewed thus had a positive view of the football identity given to the KETC which, by helping to attract tourists, would contribute to bring a set of structural improvement to life in the township, and also strengthen its cultural features, by offering its population a public image of their culture in Stellenbosch. However, some African footballers expressed doubts as to the benefits to be derived from that identity. They wished that all the clubs in the area had been involved; others wondered who would actually benefit from it all.

The football identity given to the KETC thus seemed to be primarily perceived through the positive effects that the tourist dynamics would have on the area. Indirectly it was to help change the negative image of Kayamandi and its residents, boost its economy, and reduce its dependence on the downtown area. Tourism activity at the KETC was to help do away with the stigma usually associated with the township, as a dangerous, depraved place (Guillaume 1999). Football was a cultural key that made the reality of Kayamandi accessible to tourists. A Mighty Peace player is enthusiastic about this benefit:

\begin{abstract}
It looks good. I'm not sure I could afford to walk in and have a Coke, but it's a good thing if it can attract tourists and provide jobs for people. You know, tourists are coming to Kayamandi already - foreigners mainly, Germans, Dutch, Americans. Kayamandi is not as dangerous an area as you might think. The building will help improve our image. ${ }^{33}$
\end{abstract}

Next, by means of football, the KETC was intended to bring sustainable economic activity into the area and revitalise a part of the town where business had been kept down by decades of apartheid (Beavon and Rogerson 1990). The football identity also strengthened the idea that the football clubs in the area would be the privileged beneficiaries of the initiative, that thanks to the KETC they could break through their past isolation and would find it easier to secure funding, through merchandising or sponsoring. For a Mighty 5 Stars officer, that identity was undoubtedly an economic opportunity to be seized:

\footnotetext{
But in my opinion, the place will have very positive impact on Kayamandi. It will stimulate the economy, and more and more people will be coming. The impact will be good for the economy and business ... I know my club has put in a request for a room in it, where we could show our actions and sell souvenirs. Maybe we might even meet new partners there? It's very good for the club! ${ }^{34}$
}

Last, the vitality of the KETC would help symbolically reduce the dependence of the black area on downtown, and thus do away with the centralised pattern of apartheid towns. It would make services available to the township residents, 
who previously had to go downtown for them, as a United Colors club officer expressed it:

Yes, it's a good location. In the past, we used to have to go downtown to get to places like this; now we have it right across the street. Our children now have an opportunity to use it. They won't have to take a taxi to settle administrative matters. ${ }^{35}$

The KETC's football identity was praised for its impact on the area; but above all, it boosted the pride of the Kayamandi footballers. In their eyes, that public form of recognition was neither perjury with respect to the history of football in Stellenbosch, nor a continuation or repetition of the categories of the apartheid sports order. On the one hand, it was a celebration of one feature of their culture, which was nationally and globally recognised for its contribution to the history of their emancipation - as was partly consecrated by the country being chosen to host the World Cup. Consequently it was no distortion of local history, but rather tended to restore a national reality that had long been made light of, brushed aside, marginalised. On the other hand, the public attribution was not interpreted as a continuation of the categories enforced in the past. Firstly, because that sports identity was not due to any law imposed by an authoritarian regime. Secondly, because it heightened their value, as it officially emphasised the sports quality of one group. Setting off that singularity seemed to underline an essentialist vision of the sport, and sports in general, which is widespread in South Africa: the distribution of sports among the populations is considered the expression of their natural ability, each showing excellence according to their intrinsic qualities. In that view, it only abided by the sports logic considered legitimate in the country, as a Mighty Peace officer explained:

To me, there is nothing unfair about Kayamandi being selected to host this building. We Africans are the best at football. We are not the fastest ones, for we don't have speed. But as far as that round ball is concerned, we are good; we are even excellent at handling it. It runs in our veins, we feed on football. The whites are good at rugby and cricket, I can't deny that. The coloureds are good at running, they are fast. But we are very good at football, at dribbles, at shibobos. ${ }^{36}$ That sport is really ours. It's written in our fates. The best teams of the town come from our area, so it's right for the building to be here. ${ }^{37}$

For African footballers, that they should be given monopoly of the football identity in Stellenbosch through the KETC was not regarded as being unfair to coloured footballers. On the one hand, in Stellenbosch, African footballers, their clubs, their play were reputedly excellent; and on the other hand, in view of the past, the initiative was a legitimate catching-up measure which, if it came true, by means of football, should not make the coloureds jealous, as they too, in the past, had got favours from the town authorities, as a United Colors player recalls:

I don't mean to say that it's unfair or they are excluded, because it would have been just as unfair if the building had been located at Cloetesville or Idas Valley. And we shouldn't feel guilty about it; it's right as it is and that is that, there's nothing more to 
be said. They just have to accept it, as Kayamandi accepted in the past not to have any sports facilities, while they had. So I wouldn't say that Stellenbosch football conveys an unfair or discriminating image if it is only represented by Africans. ${ }^{38}$

Thus the football identity of the KETC was generally viewed as legitimate by the Kayamandi footballers - football alone could represent the sports culture of the township and its residents. However, a few football players were wary about it and expressed reservations about how far Kayamandi residents approved of that identity: not that it had been a wrong choice, but because they were unlikely to use it, as the KETC stood some distance away from the football world of the township, and was accessible only to a privileged minority of the population.

The primary criticism against the KETC from African footballers, then, was that the project had been conducted with no participation from the Kayamandi clubs; that it resulted from the decision of a few local politicians and businessmen who had failed to ask for the advice of the clubs or of the population of the area. The KETC and its football identity were thus perceived as a privilege offered to a few investors who would make profit out of the fame of African football. That it should be their preserve, that the clubs in the area would not have access to it, fed the idea that there was a divide between two different footballs, two different football identities - the one flaunted for tourists, and the other, the real one, which was being kept thriving by the clubs, but had not really been recognised. Such rejection was predictably the first reason why the KETC's declared identity failed to gain approval, as a Mighty 5 Star officer stated:

You know, the building is named the Corridor. They want to attract the attention of tourists and companies for the World Cup. But in fact I wonder: Will the community really benefit from this building? Up to now, nobody has ever come to discuss with any officer in my club or with myself about how we could participate in the project. And yet, 'Home to Football 2010' is written on the front, and we are one of the largest clubs in the township. But nobody has come to discuss with us; I think they don't want to share. ${ }^{39}$

Another reason why that identity failed to be accepted was the economic exclusion of which the KETC was a symbol, as it was not accessible to the poorer majority in Kayamandi. Only a small group of well-off residents would have the privilege of going there, enjoying its facilities and thereby making the football identity offered there their own. For the majority, the KETC would be an inaccessible territory that would only strengthen the feeling that they were being excluded and that the world was divided into two parts. As they had no choice, they began to mobilise for other, more accessible and fulfilling football identities than the one offered by the KETC, which eventually had little claim on people's affection, however legitimate it seemed for the area, thus dwindling away as a symbol shared by the whole of the population of Kayamandi. As one United Colors player pointed out:

There will be a restaurant in the building; but who can afford to go there? Not the people in this area. They say they want to develop Kayamandi, attract tourists here. Well, that's all very well, but basically it won't improve the quality of living here. 
What do I want with a restaurant I can't afford to go to? How will this building benefit my club? I really don't see how. The community will not benefit from this attraction. The town council will, and the people who participate in it will, but I'm sure my club won't be any richer for it and we'll always find it difficult finding sponsors. ${ }^{40}$

The criticism from some African footballers against the football identity of the KETC highlighted the feeling that they were being manipulated by the elite and could not really benefit from the initiative. The latter thus appeared to be no more than a superficial 'social' measure which would bring neither any significant improvement to daily life in the neighbourhood, nor valuable assistance to its football clubs - which diminished the extent of its significance as public recognition.

\section{A Building Intended for Division and Perpetuation of the Past}

As for the SLFA officers, they mostly emphasised how the KETC's identity actually contradicted the policy of the association. Created in 2006, the latter extolled football unity built on the multicultural idea of a 'rainbow' nation. For the current leaders, football offered an opportunity to bring together formerly separate communities and work to ease the tension between the different groups, a legacy of history in Stellenbosch, as expressed in the motto of the association: Together Everybody Achieves More. That intention also underlay the remarks they directed at the public image of the KETC, which in their view was extremely awkward, considering the political past of the country and the local sports background. ${ }^{41}$ Besides, though the SLFA had been involved in the project, the members regretted that they had been brought in so late in the day, and that their objections had not been taken into consideration. They also regretted that the football identity was conferred on a building in the township primarily for reasons of political strategy. The deputy chairperson of the association explained the reason for this:

\footnotetext{
I think that generally speaking the government, particularly the local government, is suffering from a kind of guilt that urges them to do something for Africans. Unfortunately such a policy excludes the other communities who were considered as black in the past, i.e. the coloureds and the Asians. There is strong determination in that respect among town council leaders. The World Cup only expanded it. On this occasion, they want to show to the world that Africans are well treated and get plenty of facilities, that those people who live in shacks are being assisted. ${ }^{42}$
}

The determination was risky, in the view of the SLFA members who disapproved of it. They thought it dangerous to start a tourist initiative based on football in the African part of the town only to stave off possible criticism, and that it was irresponsible. The chairperson of the association, who considered it social nonsense, explained his view as follows:

Such an initiative will cause tension, will divide the communities in the town rather than unify them. It does not seem very serious, investing such amounts while you see how Kayamandi still has difficulties getting equipped with such basic services as water, electricity and decent housing ... What will the poorer Kayamandi residents say, when they realise that the town council has built a tourist building and a brand 
new stadium while they still have housing problems? They will say that after 2010 they will have a beautiful stadium, but no running water, no electricity. I think the initiative was irresponsible, they are only trying to get political visibility! ${ }^{43}$

But the most serious issue was the image of football advertised through the KETC - an exclusively African sport in Stellenbosch, which fuelled a rather dangerous trend: a brand of communitarianism in which the 'race' criterion played a crucial role in delimiting the social boundaries between the different groups, with social issues only aggravating the divides. In the view of a member of the executive committee of the association, the reification expressed by the football identity given to the KETC would only increase the hostility between populations who used to share a 'non racial' ideal:

There is now strong division between the groups in the population who in the days of apartheid were all recognised as coloured, and are no longer identified as African now. That will cause a lot of tension, because there are consequent differences in treatment. Only those communities who speak African languages are identified as such. ${ }^{44}$

The KETC was thus a symbol of essentialisation, which stood in contrast to the multicultural, 'colour-blind' management of football, which the SLFA daily enforced through the participation of members of every community in the various committees of the association, the use of English during the meetings, the ritual exchange of shirts during youth tournaments, etc (Cubizolles 2010). Based on these principles, the SLFA deputy chairperson observed how the tourist building also stood in contradiction with equitable management of the 2010 World Cup in Stellenbosch:

Because it excludes other football playing communities in the township, such as Idas Valley, Cloetesville, Jamestown or the rural areas. I think it's OK for us to host a foreign team during the World Cup, but I wish everybody could benefit from it, not just one area. I don't like discrimination, but why should Kayamandi alone have the privilege of hosting those football players? That would be discriminating the coloureds and the whites. The aim would be to make Stellenbosch, not just one area, a football town. ${ }^{45}$

The chairperson of the association also thought that the tourist building might mean that the African community would keep it to itself, which was undesirable, both in a project on multicultural management of football, and in a wider social project:

Building that facility at that particular place means that coloured people are kept away from downtown. From the point of view of politics as well as of community unification, I don't think it was a good thing. ${ }^{46}$

In their criticism, SLFA leaders also warned against another trap which making football part of the heritage in Stellenbosch, traditionally a rugby town, would imply. Reinforcing a representation of football as exclusively African contributed to excluding the white population who historically kept away from the sport for cultural reasons. This, in view of the national unity project developed for the 2010 World Cup, the KETC's more ethnic identity seemed a peculiarly limited 
initiative in the eyes of SLFA members. It did not in fact bring together the ethnic groups of one and the same town, who had long lived apart from one another. For a member of the association's executive committee, the identity given to the KETC was in contradiction with the efforts they should provide, to bring all the parties together and keep open to the others' views:

\footnotetext{
Again, I don't think it's a good thing, having that building out there; it reproduces the past, the idea that football is a black sport and so that it should be left to the blacks to play it. Such an attitude is not responsible; it excludes other communities, such as the whites. We need to create collective enthusiasm for the love of football, so that people who were not interested get to like it. It's not with a building dedicated to football in Kayamandi that more people in Stellenbosch will get interested in football. ${ }^{47}$
}

SLFA executives declared repeatedly that the identity given to the KETC meant that each community was sent back to their own area. That public image contributed to confining the different cultures to a social order based on the 'race' criterion, thus reproducing the confinement formerly established by the apartheid system. The chairperson of the SLFA, a man strongly influenced by the "non racial' sports ideal developed in the years of struggle for liberation, wished that the football identity had been conferred on a building downtown, to avert risks of its stirring any dissension or discourses promoting distinctive ethnic identities.

\section{Incorporating a Popular Sport into the Cultural Heritage in Post- Apartheid SA}

As the differing views of the stakeholders show, marketing African football by means of a tourist initiative raised a variety of responses all questioning its legitimacy, among the football community in Stellenbosch. The initiative was an attempt to change the local football order, and even the social order. First, it was promoting a public image that propounded that the African population was the one group that owned football in Stellenbosch, dispossessing the other populations of the town in the process. Such 'ownership' was all the more strongly asserted, as J and J Comaroff (2008) showed concerning the marketing of the San or Bafokeng culture, because the marketing of football in fact reinforced the idea that Africans had exclusive rights to it, that their group held a 'patent' on the practice. In Stellenbosch, the reification made the boundaries between the populations still sharper, as on that principle each of the latter defined their own identity based on a set of identified cultural practices and traits of which they thought they were the intellectual owners, and which are commonly summarised in some 'ethnic' or 'racial' category. However in another sense that public image was an important shift of definition of the social order in Stellenbosch in a wider sense as the African population, through football, was being integrated into the cultural history of the town.

Nevertheless the operation was inspired by tourist-related objectives. As Hughes has put it (2003), in South Africa integrating anything into the cultural patrimony 
is strongly influenced by tourism, which is at the heart of the economic development of the country. First, the version of football delivered by the KETC met the expectations of foreign tourists on South African football, who largely regard it as a black sport played in the poorer areas, where it had 'fought' apartheid. This was quite different from projects like the Football Heritage Complex, which was planned to be built in Durban (Alegi 2006, 2008). This was intended for foreign and local tourists, but also to help the football-playing community of the town by making training available to club leaders, referees and coaches. The KETC on the other hand was intended only for foreign tourists, who were expected to make it financially sustainable.

Incorporating football into the patrimony of a place generally considered a white, rugby town, could have been a strong symbol of the new South Africa - a public image that would have helped heal past traumas (Meskell and Scheermeyer 2008). It would also point to the promise of the World Cup as ensuring social equity and recognition for all South African football players. As Alegi wrote, 'the sport of the Black majority (i.e. Africans, Indians, Coloureds), football offered us unique opportunities to link liberation struggle narratives with the historical experience of ordinary people' (Alegi 2006:416). Through football, the identity given to the KETC could then have successfully, and in quite a novel way illustrated the promise often made to South Africans - that their complex patrimony, which had formerly been ignored, would be promoted; that the racism previously enforced would be fought out; and that a new national identity, a new sense of citizenship, would be built up.

\section{Conclusion}

Though the KETC was closed during my visits in 2008 and 2009, I visited it in 2010 and 2011. In 2010 there was only a restaurant and café, the Harborone Afrika Jazz Café, and a giant screen to broadcast the World Cup matches. Most of the booths and shops were empty, as they were after the 2010 World Cup. As the local newspaper, the Eikestad News, wrote in August 2010: 'Tourism corridor is "empty" " ${ }^{48}$ But by September 2011 the number of partners occupying the KETC premise had increased. There was an Internet café, the Entabeni Cybercafé; Kwela-Kwela Afrika, a graphic reproduction firm; a wine shop, Remongo Winery; a development firm, the Red Door Real Enterprise development; a hairdresser's, Hair Ntosh Salon; a shop being put up, the Mammals Shop; a Standard Bank ATM; the headquarters of an association, Oak Kaya, and town council offices used for the 2011 Census. However, though most of the space was then occupied, the KETC booths, where local craftsmen were to re-create a market atmosphere, were still empty. One year after the 2010 World Cup, the only traces left of the tournament and the 'Great Stellenbosch 2010' project in the building were, not a museum, but a framed Bafana-Bafana shirt, a poster of the 'Great Stellenbosch 2010' project, and two small paintings by Atida, a Kayamandi painter, who had painted a football match being played in a stadium near Table Mountain and a 
game of street football played in a township. This was a very meagre legacy indeed, if we compare it with what had been envisioned.

\section{Note on Contributor}

Sylvain Cubizolles is a French researcher in Sociology of Sport at Université de La Réunion, UFR SHE, Laboratoire DIMPS, Département STAPS.

\section{Notes}

1. In the course of our investigation we interviewed two representatives of the Stellenbosch University football club on what football identity they thought KETC had. They did not feel concerned by the initiative; nor did they have any particular feelings, only a certain indifference which could be accounted for through the fact that the University of Stellenbosch had set up its own football programme for tourists for the 2010 World Cup.

2. The three football town leagues were: the Stellenbosch Football Union, which included the coloured clubs from the outskirts of the town and the university club; the Winelands Football Association, of which the members were coloured and African clubs from the outlying areas and rural neighbourhoods; the Kayamandi Football Association, which included the African clubs of the township: Kayamandi.

3. Stellenbosch interview, April 2008.

4. SA Tourism/KPMG (2006) South Africa: Domestic Tourism Growth Strategy. Final Report Revised Value, http://www.southafrica.net/satourism/research/; Statistics South Africa (2008) 'Tourism, 2008', Tourism Statistics, Report 03-51-02.

5. Cape Town Routes Unlimited (2009) Western Cape Tourism Barometer 3(2), http://www. tourismstellenbosch.co.za/

6. Survey Direct Economic Impact of STI Members 2008, http://www.stellenboschtourism.co.za.

7. 'Municipality strengthens partnership with tourism association', Stellenbosch Newsletter August 2009:2, http://www.stellenbosch.gov.za.

8. '2010 Soccer World Cup: how will the greater Stellenbosch benefit?', Stellenbosch Newsletter March 2008.

9. 'Town's 2010 strategy', Eikestad News 16 January 2009:9.

10. 'ANC wins Stellenbosch Council back from the DA', Cape Times 8 April 2008.

11. See http://2010.stellenbosch.gov.za/home.php

12. Stellenbosch interview, May 2009.

13. Kayamandi Urban Renewal, http://www.dmp.co.za/services/popup.php?id=31

14. 'Integrated Development Plan for the municipal area of Stellenbosch', in Stellenbosch Municipality Integrated Development Plan, 29 May 2007.

15. Ibid:10.

16. Kayamandi Tourism Centre (2008) Dennis Moss Partnership Company Portfolio Summary.

17. 'Status of the Kayamandi Tourism Precinct', Stellenbosch Municipality Newsletter 3 March 2008.

18. Stellenbosch Interview, May 2009.

19. 'Town's 2010 strategy', Eikestad News 16 January 2009:9.

20. 'Soccer legend spreads the 2010 message in Stellenbosch', Stellenbosch Newsletter October 2009:1.

21. See http://www.facebook.com/pages/Kayamandi-Economic-Tourism-Corridor

22. Kayamandi Tourism Centre (2008) Dennis Moss Partnership Company Portfolio Summary.

23. Kayamandi Tourism Centre (2007) Architect and Builder 58(5):3.

24. Ibid. 
25. The word 'race' is used between inverted commas to emphasise how it is offending in nature and derogatory in use. However, it does express coloured footballers' feeling - that the inequality they have to endure is mostly related to that criterion, which is still central in South African politics, particularly in the government's efforts to remedy the different forms of inequality from the past.

26. Stellenbosch interview, April 2008.

27. Stellenbosch interview, May 2009.

28. Ibid.

29. Stellenbosch interview, April 2008.

30. Stellenbosch interview, May 2009.

31. Stellenbosch interview, April 2008.

32. Ibid.

33. Stellenbosch interview, May 2009.

34. Stellenbosch interview, April 2008.

35. Stellenbosch interview, May 2009.

36. Shibobo is a dribble that consists in running the ball between an opponent's legs with a view to getting him eliminated.

37. Stellenbosch interview, April 2009.

38. Stellenbosch interview, May 2009.

39. Ibid.

40. Ibid.

41. The Stellenbosch Sport and Recreation Association officer, who is in charge of collecting requests from all the sports clubs in the town, whatever the sport, and forwarding them to the municipal Sport and Recreation department, observed that the other sports complained about the increased attention paid to football in preparation for the World Cup. Stellenbosch interview, April 2008.

42. Stellenbosch interview, April 2008.

43. Ibid.

44. Ibid.

45. Ibid.

46. Ibid.

47. Stellenbosch interview, May 2009.

48. 'Tourism corridor is "empty", Eikestad News 27 August 2010:9.

\section{References}

Adhikari, M. 2005. Not White Enough, Not Black Enough. Racial Identity in the South African Coloured Community. Ohio US: Center for international Studies, Ohio University.

Alegi, P. 2006. 'The Football Heritage Complex: History, Tourism and Development in South Africa'. Afrika Spectrum 41(3):415-26.

Alegi, P. 2008. 'A Nation To Be Reckoned With': The Politics of World Cup Stadium Construction in Cape Town and Durban, South Africa'. African Studies 67(3):397-422.

Alegi, P. 2009. 'La Coupe du monde, une forme d'accomplissement pour les Sud-Africains'. Le Monde, 12 June.

Beavon, K. and Rogerson, C. 1990. 'Temporary Trading for Temporary People: The Making of Hawking in Soweto', in D. Drakakis-Smith (ed), Economic Growth and Uurbanization in Developing Areas. London: Routledge.

Comaroff, J.-L. and Comaroff, J. 2008. 'Ethnicity', in N. Shepherd and S. Robins (eds), New South African Keywords. Ohio, US: Ohio University Press.

Cubizolles, S. 2010. 'Soccer in a Rugby Town: Restructuring Football in Stellenbosch', in P. Alegi and C. Bolsmann (eds), South Africa and the Global Game, Football, Apartheid and Beyond. London: Routledge. 
Cubizolles, S. 2011. 'Finding a New Identity for a Township Club — The Case of the Mighty 5 Star in Stellenbosch'. The International Journal of the History of Sport 28(15):2191-205.

Guillaume, P. 1999. 'De l'urbanité dans les townships. Etude de Kliptown (Soweto)'. L'Espace géographique 2:148-58.

Hughes, H. 2003. 'What is remembered and what forgotten: a decade of redefining culture and heritage for tourism in South Africa'. paper presented at the conference on cultural tourism, University of Nottingham, December, http://www.lincoln.ac.uk.

Hughes, H. 2007. 'Rainbow, Renaissance, Tribes and Township: Tourism and Heritage in South Africa since 1994', in S. Buhlungu, J. Daniel, R. Southall and J. Lutchman (eds), State of the Nation, South Africa 2007. Johannesburg: HSRC Press.

Meskell, L. and Scheermeyer, C. 2008. 'Heritage as Therapy: Set Pieces from the new South Africa'. Journal of Material Culture 13(2):153-73.

Ramchander, P. 2007. 'Township Tourism - Blessing or Blight? The Case of Soweto in South Africa'. Cultural Tourism: Global and Local Perspectives. London: Routledge.

Shepherd, N. 2008. 'Heritage', in N. Shepherd and S. Robins (eds), New South African Keywords. Ohio, US: Ohio University Press.

Zietsman, H.L. 2007. 'Recent Changes in the Population Structure of Stellenbosch Municipality', Geographical Systems Research Bureau Stellenbosch, http://www.stellenbosch.gov.za/jsp/util/ document.jsp?id1/4778. 